\title{
Preinterventional screening of the TAVI patient: how to choose the suitable patient and the best procedure
}

\author{
Crochan J. O'Sullivan · Stefan Stortecky • \\ Lutz Buellesfeld · Peter Wenaweser • \\ Stephan Windecker
}

Received: 6 August 2013/Accepted: 16 October 2013/Published online: 11 February 2014

(C) Springer-Verlag Berlin Heidelberg 2014

\begin{abstract}
Transcatheter aortic valve implantation (TAVI) is a novel therapy, which has transformed the management of inoperable patients presenting with symptomatic severe aortic stenosis (AS). It is also a proven and less invasive alternative therapeutic option for high-risk symptomatic patients presenting with severe AS who are otherwise eligible for surgical aortic valve replacement. Patient age is not strictly a limitation for TAVI but since this procedure is currently restricted to high-risk and inoperable patients, it follows that most patients selected for TAVI are at an advanced age. Patient frailty and co-morbidities need to be assessed and a clinical judgment made on whether the patient will gain a measureable improvement in their quality of life. Risk stratification has assumed a central role in selecting suitable patients and surgical risk algorithms have proven helpful in this regard. However, limitations exist with these risk models, which must be understood in the context of TAVI. When making final treatment decisions, it is essential that a collaborative multidisciplinary "heart team" be involved and this is stressed in the most recent guidelines of the European Society of Cardiology. Choosing the best procedure is contingent upon anatomical feasibility, and multimodality imaging has emerged as an integral component of the pre-interventional screening process in this regard. The transfemoral route is now
\end{abstract}

This article is part of a series of 3 articles on TAVI that will be published in subsequent issues.

C. J. O’Sullivan · S. Stortecky $\cdot$ L. Buellesfeld

P. Wenaweser $\cdot S$. Windecker $(\bowtie)$

Department of Cardiology, Swiss Cardiovascular Center Bern,

Bern University Hospital, 3010 Bern, Switzerland

e-mail: stephan.windecker@insel.ch

C. J. O'Sullivan

e-mail: crosullivan@hotmail.com considered the default approach although vascular complications remain a concern. A minimal vessel diameter of $6 \mathrm{~mm}$ is required for currently commercial available vascular introducer sheaths. Several alternative access routes are available to choose from when confronted with difficult iliofemoral anatomy such as severe peripheral vascular disease or diffuse circumferential vessel calcification. The degree of aortic valve leaflet and annular calcification also needs to be assessed as the latter is a risk factor for postprocedural paravalvular aortic regurgitation. The ultimate goal of patient selection is to achieve the highest procedural success rate while minimizing complications and to choose patients most likely to derive tangible benefit from this procedure.

Keywords Transcatheter aortic valve implantation . Aortic stenosis $\cdot$ Patient selection $\cdot$ Multimodality imaging

\section{Introduction}

Transcatheter aortic valve implantation (TAVI) is a novel therapeutic modality to treat high-risk or inoperable patients presenting with symptomatic severe aortic stenosis (AS) $[1,2]$. Appropriate patient selection is critical to the success of this procedure and must take into consideration several clinical and anatomical factors [3]. Clinical factors include a careful assessment of symptomatic status, aortic stenosis severity and patient risk profile. Risk stratification has assumed a key role in patient selection and the most recent guidelines from the European Society of Cardiology (ESC) have stressed the importance of a multidisciplinary "heart team" approach to help determine this risk [4]. Traditionally, algorithms derived from cardiac surgical patients have been used as an adjunct to help quantify risk 
Fig. 1 Clinical decision algorithm for patients presenting with severe Adapted and modified from Webb et al. [9] with permission from Elsevier. $A V R$ aortic valve replacement, TAVI transcatheter aortic valve replacement symptomatic aortic stenosis.

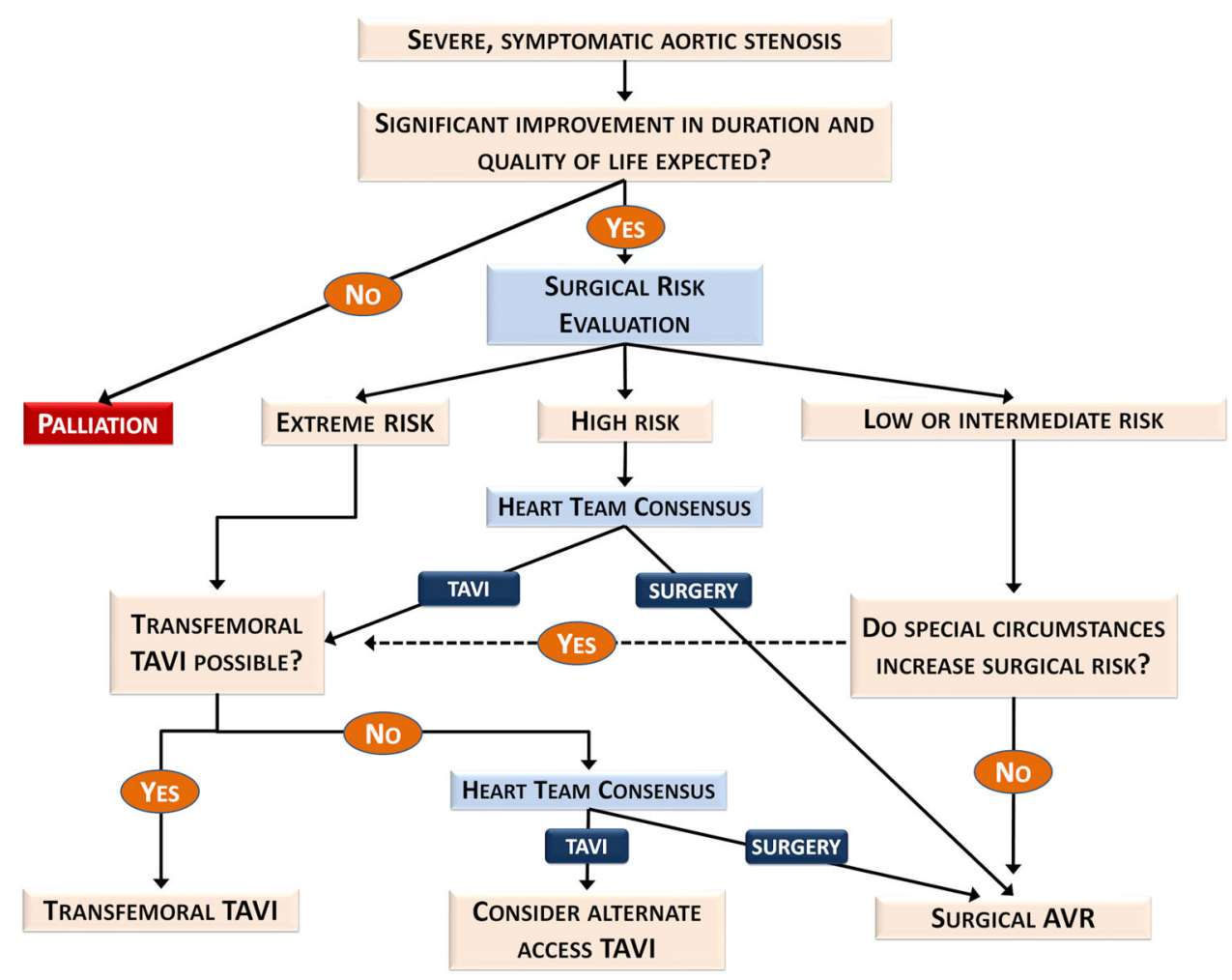

among patients undergoing TAVI [5]. However, there are inherent limitations with this approach, mainly deriving from the fact that existing risk algorithms are being applied to procedures and patient populations for which they were not originally intended [6]. Consequently, the use of risk models alone may not provide a satisfactory risk assessment and other clinical factors must be considered [5].

Anatomical elements include a comprehensive assessment of the peripheral vessels, aorta, aortic annulus, left ventricular outflow tract (LVOT) and left ventricle. Multimodality imaging plays a pivotal role in this regard [7]. Understanding the topographic anatomy of the aortic valve complex and its relationship to surrounding structures such as the atrioventricular conduction system, mitral valve apparatus and coronary ostia is crucial [8]. Selection of prosthesis type and size relies on precise measurements of the aortic valve annulus, whereas selection of the procedural approach depends in large part on the luminal diameter, calcific burden and tortuosity of the peripheral arteries and/or the presence of significant atheroma within the thoracic aorta.

\section{How to choose the suitable patient}

\section{Clinical factors}

According to recent ESC guidelines, TAVI is indicated to treat symptomatic severe aortic stenosis in selected high risk or inoperable patients as assessed by a "heart team" [4]. The latter should comprise cardiologists, cardiac surgeons and other specialists if deemed necessary. The guidelines state that selected patients should be expected to gain improvement in their quality of life and to have a life expectancy of $>1$ year after consideration of their comorbidities [4]. A recently proposed algorithm for clinical decision making in TAVI is shown in Fig. 1 [9]. It should be noted that some patients are even too high risk for TAVI and significant co-morbidities (e.g., severe COPD) may lead to continued impaired quality of life and impact on mortality even after TAVI [10].

\section{Risk assessment}

Traditionally, surgical risk scores have been used to assess patient risk and there are several risk scoring systems available for those undergoing surgical aortic valve replacement (SAVR) (Table 1) [11-19]. The most widely used risk algorithms are the European System for Cardiac Operative Risk Evaluation (EuroSCORE) and the Society of Thoracic Surgeons Predicted Risk Of Mortality (STSPROM) scores [11, 13]. These scores, in general, provide reasonable discrimination, i.e. overall estimation of risk category, but cannot be used to estimate the precise operative mortality in an individual patient because of poor calibration, particularly in high-risk patients [5]. For example, in the high-risk Placement of Aortic Transcatheter Valves (PARTNER) A cohort, the mean STS-PROM 


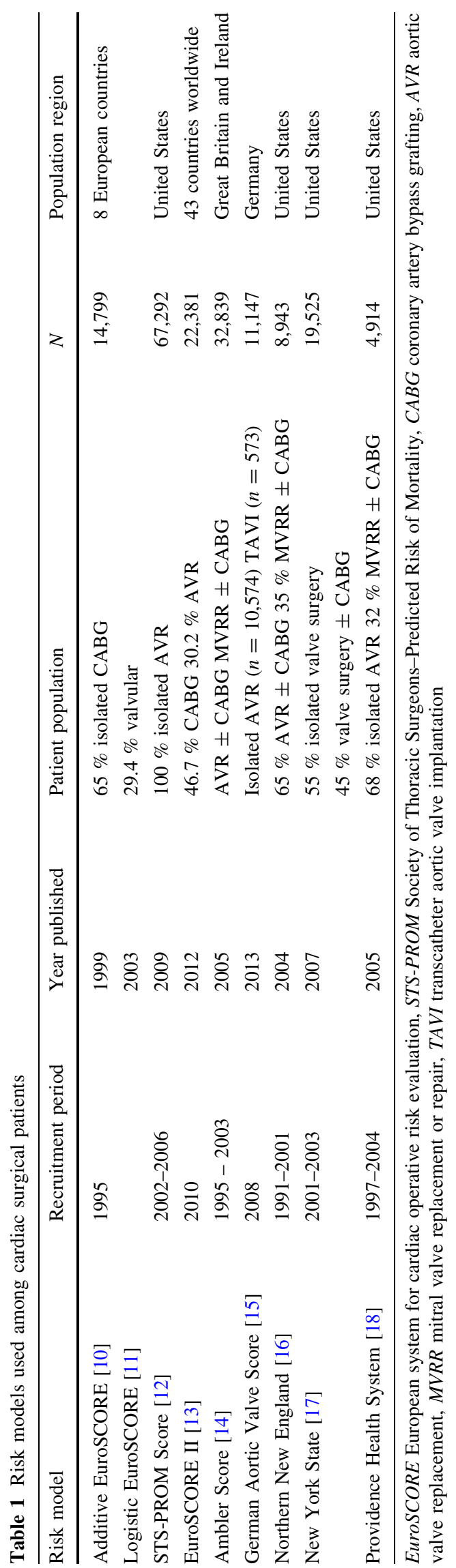

scores were 11.8 and $11.7 \%$ and the mean logistic EuroSCOREs were 29.3 and $29.2 \%$ in the TAVI and SAVR groups, respectively [20]. However, the observed 30-day mortality rates were lower at 3.4 and $6.5 \%$ in the respective groups [20]. In fact, the logistic EuroSCORE has been shown to overpredict expected mortality by a factor of three or more in high-risk candidates for SAVR [6]. This poor calibration among high-risk valvular disease patients relates to the fact that the EuroSCORE model was developed and validated in a population of lower risk patients undergoing predominantly coronary artery bypass grafting (CABG) almost two decades ago [11]. The STS-PROM risk model for SAVR is more precise, which is not surprising given that it was developed and validated in a more contemporary group of patients exclusively undergoing isolated aortic valve replacement [13]. The EuroSCORE II model, which was developed and validated in a large contemporary population of patients recruited worldwide [14], was found to be better calibrated than the logistic EuroSCORE in predicting outcomes after TAVI [21, 22]. However, almost half of recruited patients underwent CABG, thereby limiting its applicability to patients undergoing exclusively valvular procedures. The recent German Aortic Valve (AV) Score was developed from a population of patients entirely undergoing aortic valve procedures [isolated SAVR $(n=10,574)$ or TAVI $(n=573)$ ] throughout Germany in 2008 [16]. This novel risk model appears promising, although further studies are required to assess the discrimination and calibration of the German AV Score among a TAVI population. A major limitation in applying cardiac surgical risk models to TAVI patients is that there are several variables that impact upon clinical outcomes among selected patients undergoing TAVI that are not captured, including liver disease, porcelain aorta, adherent coronary artery bypass grafts, previous radiation to the chest, and frailty [5]. While surgical risk scores are not perfect when applied to a TAVI patient population, they are currently the best available risk stratification tools and should be used as an adjunct to estimate patient risk. However, they should not be used in isolation and clinical judgment is required. Whether a dedicated "TAVI risk score" will improve discrimination and calibration remains to be seen.

Anatomical factors

\section{Peripheral arteries}

The peripheral arteries can be imaged using a variety of methods, including contrast angiography, intravascular ultrasound, multidetector computed tomography (MDCT) or magnetic resonance imaging (MRI) (Fig. 2). Important parameters to consider are the diameter, extent of 
Fig. 2 Imaging of the femoral arteries using contrast angiography (a) and threedimensional reconstruction using multidetector computed tomography (MDCT) (b).

Preinterventional multimodality imaging is important to assess the minimal femoral diameters, calcific burden and degree of tortuosity of the peripheral vessels
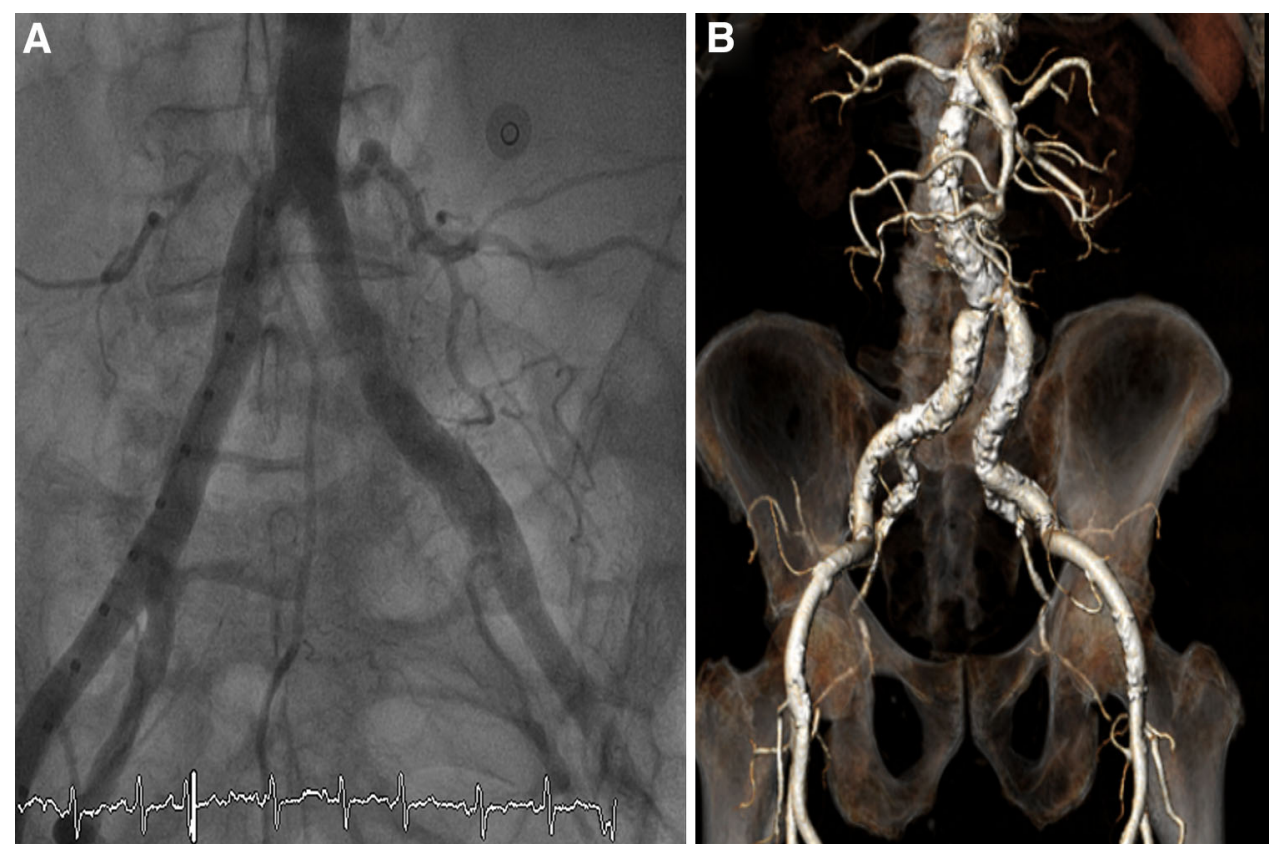

calcification and tortuosity of the peripheral arteries as well as their combination. The ratio between the outer sheath diameter and the internal diameter of the femoral artery using quantitative angiography yields the Sheath to Femoral Artery Ratio (SFAR) [23]. An SFAR ratio of $>1.05$ has been shown to predict Valvular Academic Research Consortium (VARC) defined major vascular complications and 30-day mortality in one study [23]. However, the SFAR ratio can be increased to 1.10 in the absence of significant calcification, but is reduced to 1.00 in the presence of circumferential calcification [23]. A recent study showed that vascular complications are more frequent in three scenarios: (1) minimal artery diameter is smaller than the external sheath diameter (2) moderate or severe vessel calcification and (3) peripheral vascular disease [24]. Contrast angiography can provide a gross assessment of lumen diameter and vessel tortuosity of the peripheral vessels and enables internal diameter measurement [25]. However, MDCT is assuming a more prominent role for imaging the peripheral vessels owing to improved definition and its 3 dimensional (3D) capabilities [26]. Furthermore, the use of CT image post-processing software such as 3-mensio Valves ${ }^{\mathrm{TM}}$ (3mensio Medical Imaging $\mathrm{BV}$, Bilthoven, The Netherlands) allows for the 3D reconstruction of the iliofemoral arteries and descending aorta in a simplified manner [27]. In general, the side with the larger, less tortuous, less diseased iliofemoral artery is selected for sheath insertion. The transfemoral approach should be avoided in patients with vessel diameters too small to accommodate the introducer sheaths (Table 2) and in patients with severe peripheral vascular disease and diffuse circumferential severe calcification of the iliofemoral vasculature.

\section{Ascending aorta}

Accurate measurement of ascending aortic diameter is important for the self-expanding Medtronic CoreValve bioprosthesis (Medtronic, Inc. Minneapolis, Minnesota), because the outflow portion of the frame abuts this region of the vessel wall to orient the prosthesis in the direction of blood flow [28]. A dilated ascending aorta $(>43 \mathrm{~mm})$ is a relative contraindication for Medtronic CoreValve implantation. Adequate sinus of Valsalva dimensions is also necessary to accommodate the displaced native leaflets following CoreValve implantation. Balloon-expandable SAPIEN valves (Edwards Lifesciences, Inc., Irvine, CA, USA), once implanted, are located almost exclusively within the annular plane and, therefore, ascending aorta dimensions are less relevant. Critically important for these prostheses, however, is the height between the aortic annulus and the right and left coronary ostia (Fig. 3) [28]. Coronary obstruction may occur when a bulky calcified aortic valve leaflet is compressed against the coronary ostium following implantation of a balloon-expandable valve. Therefore, a minimum distance of $8-10 \mathrm{~mm}$ between the coronary ostia and aortic annular plane is recommended by the manufacturer when implanting a SAPIEN valve [28]. In the presence of adequate sinus of Valsalva dimensions, this annular-ostial height prerequisite is not essential for CoreValve implantation, owing to its constrained mid portion. 


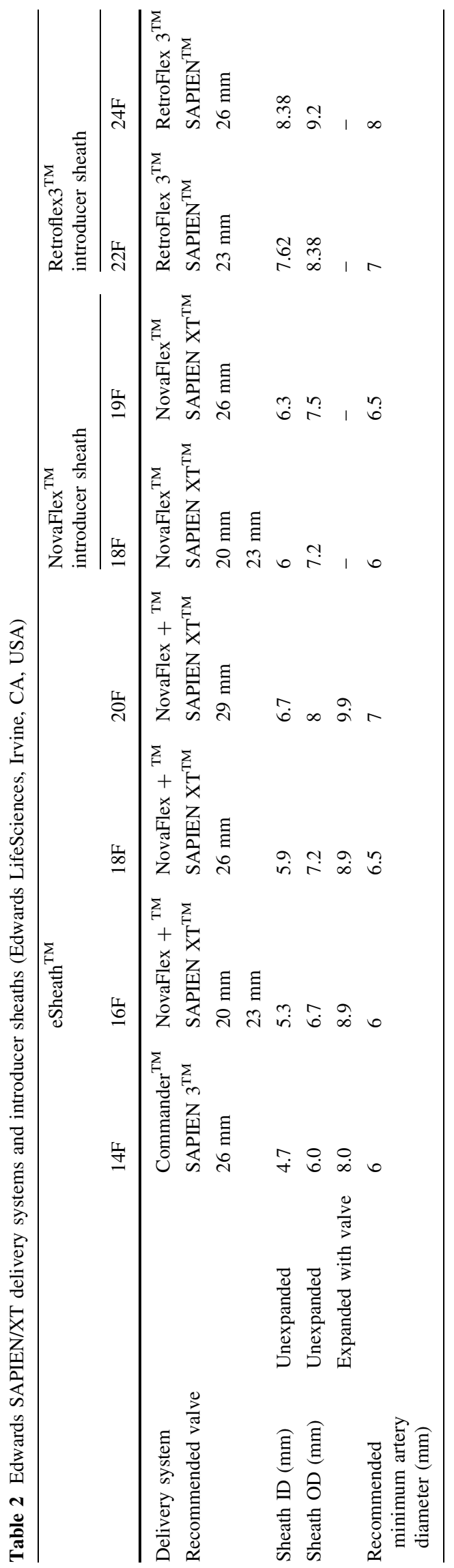

\section{Aortic annulus}

Precise annular measurements using non-invasive imaging are crucial for procedural success and avoidance of complications. In addition, a detailed knowledge of aortic root anatomy is essential. The surgical aortic annulus is a semilunar crown-like ring delineated by the hinges of the aortic valve leaflets [8]. The aortic annulus used for the purposes of aortic prosthesis sizing concerns a virtual ring formed by the basal attachments of the aortic valve cusps located at the base of the crown (Fig. 4). This virtual ring is distinct from the anatomic ventriculoarterial junction, which is located slightly more distally within the aortic root [8]. The ring formed at the top of the crown represents a true ring and forms the sinotubular junction, which demarcates the border between the aortic root and the ascending aorta. In the context of TAVI, noteworthy structures in close proximity to the aortic valve complex include the anterior mitral valve leaflet and left bundle branch [8]. The noncoronary and left coronary aortic leaflets are in fibrous continuity with the anterior mitral valve leaflet, which together form the aortic-mitral curtain. The left bundle branch is located close to the base of the interleaflet triangle separating the non-coronary and right coronary leaflets of the aortic valve [8].

Accurate aortic annular measurements are critical to avoid annulus-prosthesis mismatch [29]. The latter may lead to either undersizing or oversizing of transcatheter heart valve (THV) prostheses [29]. Undersizing may result in paravalvular regurgitation and/or device embolization, whereas oversizing may cause underexpansion of the prosthesis, conduction disturbances or annular rupture. A recent study reported that aggressive annular area oversizing $(\geq 20 \%)$ was associated with an increased risk of aortic root rupture (odds ratio 8.38) during TAVI with balloon-expandable prostheses [30]. A certain degree of oversizing is necessary, however, to anchor the sutureless prosthesis to the annular wall and provide adequate sealing against paravalvular aortic regurgitation. Caution is required though, particularly in the presence of excessive valvular calcification as well as calcification extending into the LVOT or ascending aorta [30].

Traditionally, annular diameters were measured as the distance between the hingepoints of the right and noncoronary aortic cusps in mid systole from a parasternal long-axis view in transthoracic echocardiography (TTE) or a $120^{\circ}-140^{\circ}$ long-axis view (3-chamber view) in transesophageal echocardiography (TEE) (zoomed mode) [31]. In addition, the annulus can be measured following aortic root angiography [28]. However, these measurements provide only 2 dimensional assessments of the aortic annulus and ignore its 3D configuration. In addition, a 
Fig. 3 Calculating the distance between the aortic annular plane and left (a) and right

(b) coronary ostia using multidetector computed tomography (MDCT). A recent study using MDCT revealed that the mean distance between the aortic annulus and left coronary artery is

$14.4 \pm 3.6 \mathrm{~mm}$ and the mean distance between the aortic annulus and right coronary artery is $16.7 \pm 3.6 \mathrm{~mm} \mathrm{[30]}$. An adequate distance between the aortic annulus and coronary ostia $(>10 \mathrm{~mm})$ is critically important for implantation of balloon-expandable bioprostheses and must be determined during the screening process
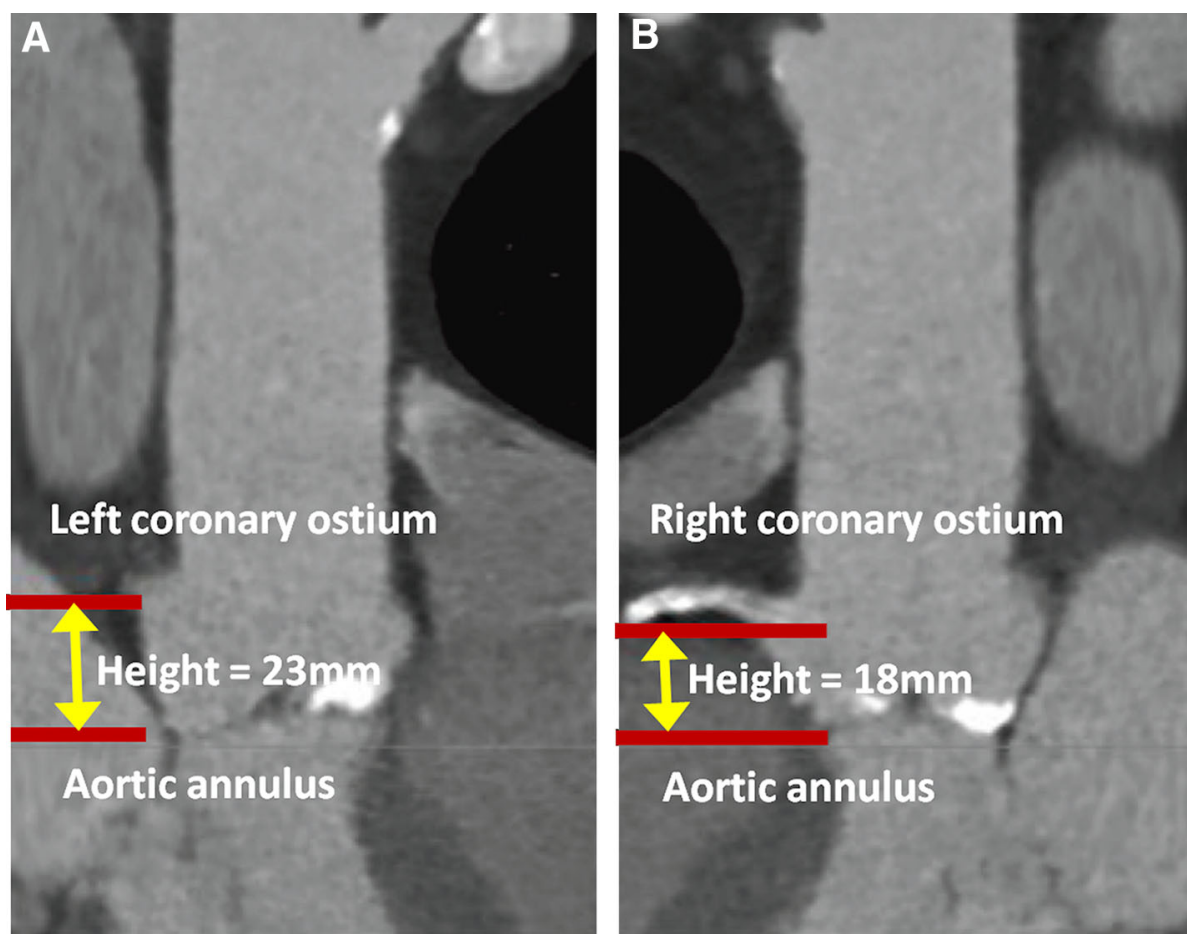

recent study reported that the aortic annulus is oval in shape in over $90 \%$ of cases [32]. Therefore, TTE and TEE may only provide tangential measurements, which may not reflect the true annular diameter. Using MDCT, 3D reconstruction is possible and, therefore, this imaging modality assumes a more prominent role in aortic annular assessments (Fig. 5) [33-35]. MDCT measurements are taken from systolic phase reconstructions ranging from 20 to $45 \%$ of the R-R interval, during retrospective electrocardiographic gating imaging, using the phase with maximum valve opening [26]. The aortic annulus plane is obtained by a double oblique multiplanar reconstruction with 2 orthogonal planes representing the short and long axis of the virtual basal ring [26].

Patients with chronic renal insufficiency undergoing TAVI may be at higher risk of acute renal failure when exposed to contrast agents during the course of MDCT screening or left heart catheterization prior to the TAVI procedure. Therefore, a staged procedure should be recommended if MDCT screening is used. Alternatively, annulus sizing might be achieved using rotational angiography (Dyna-CT) or 3D-TEE during the same procedure. A recent study showed that patients with baseline chronic kidney disease (CKD) undergoing TAVI were at no higher risk of acute kidney injury, renal replacement therapy and mortality than patients without CKD [36].

Considerable debate exists regarding the best parameter for annular sizing [30, 34, 37, 38]. While diameter measurements are recommended by manufacturers' guidelines, some argue that area measurements are more reproducible and have been shown to be predictive of greater than mild paravalvular regurgitation [37, 38]. Others have advocated perimeter annular measurements owing to less variability across the cardiac cycle [39]. In addition, perimeter measurements are less affected by the morphological transformation of the annulus (i.e. change from oval to circular shape) that may occur following prosthesis (particularly balloon expandable) implantation [39].

When determining prosthesis size based on MDCT diameter measurements, mean annular diameters $\left(D_{\text {mean }}\right)$ derived from the minimal diameter $\left(D_{\min }\right.$; measured in the sagittal view) and maximal diameter $\left(D_{\max }\right.$; measured in the coronal view) $\left(D_{\text {mean }}=\left(D_{\min }+D_{\max }\right) / 2\right)$ or virtual aortic annular diameters should be used [33]. The latter can be calculated using either annular perimeter $\left(D_{\text {perimeter }}=\right.$ perimeter $/ \pi)$ or annular area $\left(D_{\text {area }}=2 \times \sqrt{\frac{\text { area }}{\pi}}\right)$ [33]. The MDCT sagittal view corresponds to the parasternal longaxis view on TTE and the $20^{\circ}-140^{\circ}$ long-axis view on TEE [29]. In general, annular diameters measured using TTE are smaller than those sized using TEE and both tend to be smaller than those measured on the MDCT coronal view [29].

Patients with annuli too large for currently available THV prostheses $(>29 \mathrm{~mm})$ are not suitable for TAVI. In addition, patients with large annuli and/or low-grade calcification might be at particular risk for valve displacement and this should be noted during multimodality imaging. 
Fig. 4 The aortic annulus used for the purposes of aortic prosthesis sizing concerns a virtual ring formed by the basal attachments of the aortic valve cusps located at the base of the crown. The ring formed at the top of the crown represents a true ring and forms the sinotubular junction. Figure adapted from Sinning et al. [62] and used with permission from Elsevier
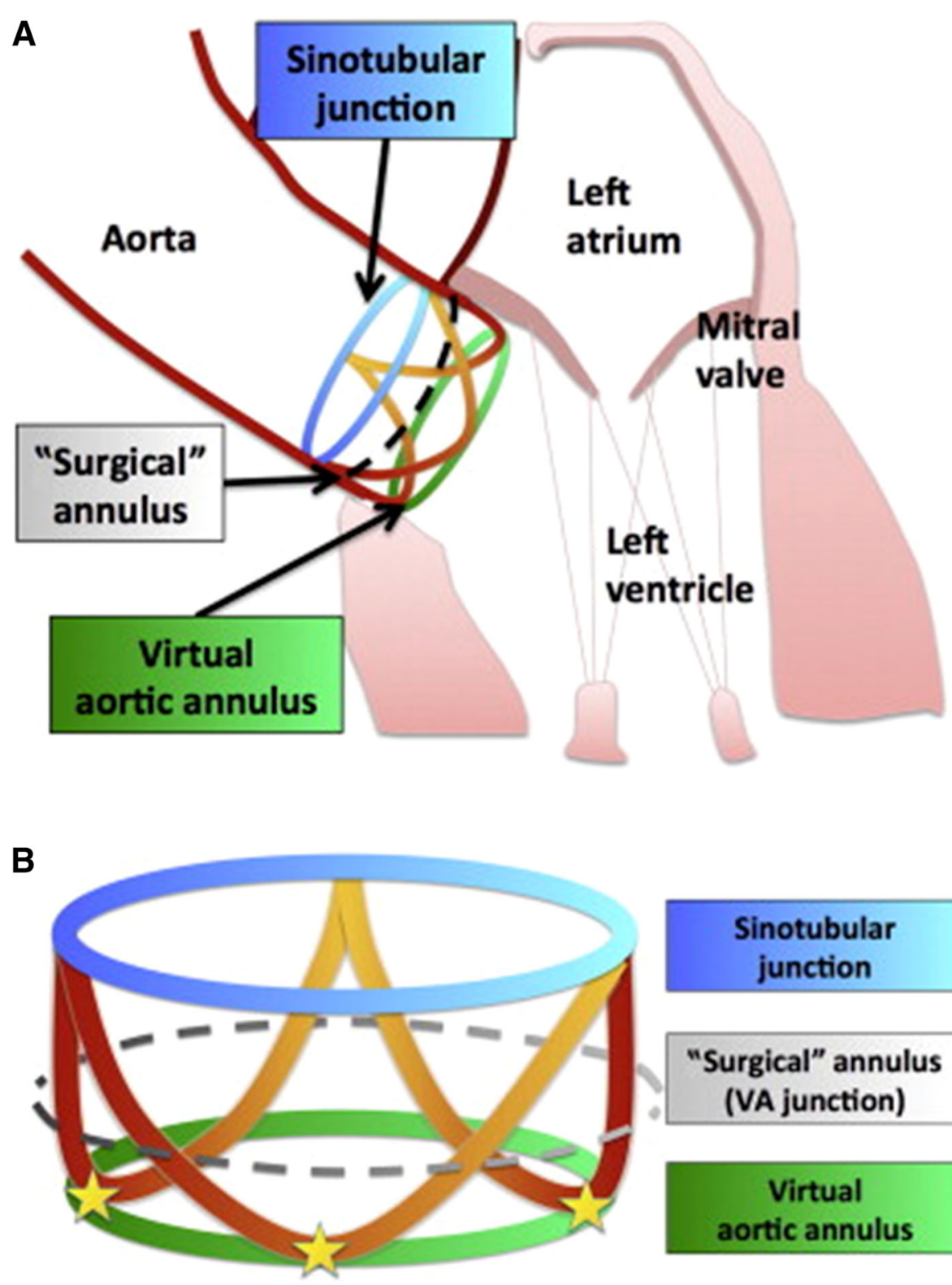

\section{Sinotubular junction}

"Surgical" annulus (VA junction)

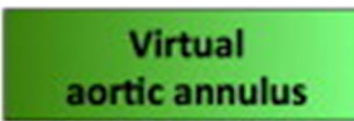

\section{Aortic valve leaflets}

Aortic valve leaflet morphology and anatomy should be evaluated. Bicuspid aortic valve anatomy is currently considered a relative contraindication for TAVI [4]. The elliptical annulus, asymmetric aortic cusps and a raphe of fusion between two cusps have raised concerns regarding prosthesis deployment and the increased risk of paravalvular regurgitation [40]. However, individual case reports and small case series have demonstrated feasibility and short-term clinical outcomes appear promising [40] but larger patient series and longer term follow-up are needed. In addition, severe calcification of the aortic valve leaflets, particular if asymmetrical, is a known cause of paravalvular aortic regurgitation and, therefore, should be evaluated during the screening process [41].

\section{Cardiac factors}

The degree of LVOT calcification should be evaluated preferably using MDCT. A recent study reported that moderate-severe calcification of the LVOT was associated with an increased risk of aortic root rupture during TAVI with balloon-expandable prostheses [30]. In cases of a pronounced sigmoid septum, the transapical approach may be preferred to allow adequate positioning and anchorage of the prosthesis [42]. 



Fig. 5 Multimodality imaging of the aortic annulus. The annulus may be imaged using the $120^{\circ}-140^{\circ}$ long-axis view (3-chamber view) in transesophageal echocardiography (a) or using multidetector computed tomography (MDCT) (b-d). The virtual annulus is

\section{Coronary artery disease}

Significant coronary artery disease is present in 40-75\% of patients undergoing TAVI [43]. Patients with coronary artery disease tend to have higher surgical risk scores and associated comorbidities than those without. The general consensus is that revascularization should be considered for severe coronary stenosis in proximal epicardial coronary vessels that subtend a large area of myocardium [43]. However, patients with severe aortic stenosis and triple vessel disease with a SYNTAX score $\geq 33$ should be considered for SAVR where feasible [43]. There is also debate regarding the timing of revascularization. Although both concomitant and staged strategies have been reported measured at the level of the basal attachments of the aortic valve leaflets (b). A multiplanar reconstruction in the coronal view enables measurements of the sinuses of Valsalva and ascending aorta (d)

successfully [44], the latter approach appears to be more commonly used [43].

\section{Low-flow, low-gradient severe aortic stenosis}

A very low $\mathrm{LVEF}(<30 \%)$ among patients with severe AS has a negative prognostic impact in patients treated conservatively [45]. However, patients presenting with a low LVEF and high gradient generally have better LVEF recovery following SAVR as compared with patients with a low LVEF in combination with a low mean gradient [46]. The latter condition is referred to as low-flow (i.e. LVEF $\leq 40 \%$ ), low-gradient (mean gradient $\leq 40 \mathrm{mmHg}$ but aortic valve area $<1 \mathrm{~cm}^{2}$ ) (LFLG) severe AS and is present 
in $5-10 \%$ of patients presenting with severe AS [47]. This condition is challenging to manage because conservatively managed patients have a dismal prognosis, yet those undergoing SAVR have a high perioperative mortality, particularly in the absence of contractile reserve [48]. A recent sub-analysis of the PARTNER trial revealed that 2-year mortality was significantly reduced (HR 0.43, $p=0.04)$ with TAVI as compared with medical management among patients $(n=42)$ with LFLG severe AS from the inoperable B cohort [49]. Recently, it was demonstrated that patients with LFLG severe AS had overall 30-day and 1-year mortality rates similar to high-gradient patients following TAVI, albeit with an higher incidence of 1-year cardiac mortality among LFLG patients [50]. It was also found that patients with a low LVEF $(\leq 40 \%)$ and highgradient (mean gradient $>40 \mathrm{mmHg}$ ) had significantly improved LVEF recovery following TAVI as compared to patients with LFLG severe AS [50]. In 2007, a novel entity, paradoxical low-flow (LVEF $\geq 50 \%$, but stroke volume index (SVI) $\left.\leq 35 \mathrm{~mL} / \mathrm{m}^{2}\right)$, low-gradient $(\leq 40 \mathrm{mmHg}$ ) severe AS (AVA $<1 \mathrm{~cm}^{2}$ ) (PLF-LG) was described and symptomatic patients managed conservatively had a higher mortality compared to patients undergoing SAVR [51]. Herrmann et al. in a post hoc analysis of the PARTNER trial showed that among the cohort of patients with PLFLG, those undergoing TAVI had significantly improved survival when compared with patients undergoing medical management $[49,52]$. A recent study reported that PLF-LG patients undergoing TAVI have a high arterial afterload despite a low mean gradient and that these patients derive functional benefit from TAVI with clinical outcomes similar to high-gradient patients [50].

\section{Contraindications to TAVI}

Clinical contraindications include a life expectancy $<1$ year or unlikely improvement in quality of life by TAVI because of comorbidities [4]. Severe concomitant primary disease of other valves which contribute predominantly to the patients' symptoms and can only be treated by surgery is another contraindication [4]. Anatomical contraindications include inadequate annulus size $(<18 \mathrm{~mm}$ or $>29 \mathrm{~mm})$, presence of left ventricular thrombus, active endocarditis, high risk of coronary obstruction (asymmetric valve calcification, short annularostial distance, small aortic sinus dimensions), large plaques with mobile thrombi in the ascending aorta or arch or inadequate vascular access (for transfemoral/subclavian approach) due to vessel size, calcification or tortuosity [4]. In addition, the ESC guidelines have stressed the absence of a "heart team" and on-site cardiac surgery as contraindications to TAVI [4]. Relative contraindications include bicuspid or non-calcified valves, and untreated coronary artery disease requiring revascularization. For the transapical approach, severe pulmonary disease and an inaccessible LV apex remain important caveats [4].

\section{How to choose the best procedure}

\section{Transcatheter heart valve bioprosthesis}

Nine THV bioprostheses have received Conformité Européenne (CE) mark approval at the time of writing (January 2014) (Table 3). The Edwards SAPIEN received Food and Drug Administration (FDA) approval in the United States (US) for clinical use in either inoperable (November 2011) or high-risk (October 2012) patients. The Medtronic CoreValve received FDA approval for clinical use in inoperable patients in January 2014. Outside the US, the two most commonly used THVs are the Edwards SAPIEN $\mathrm{XT}$ and Medtronic CoreValve devices at this point of time. The Edwards SAPIEN XT is a balloon-expandable prosthesis made from a cobalt-chromium frame, trileaflet bovine pericardial leaflets, and polyethylene terephthalate (PET) fabric skirt [53]. The leaflets undergo a proprietary anti-calcification treatment (ThermaFix ${ }^{\mathrm{TM}}$ ) process [53]. The Edwards SAPIEN XT is available in 4 sizes $(20,23$, 26 , and $29 \mathrm{~mm}$ ) and can be implanted in native annuli with diameters of $16-27 \mathrm{~mm}$. The current third-generation Medtronic CoreValve bioprosthesis is a self-expandable valve, comprising a nitinol frame, trileaflet porcine pericardial leaflets, and porcine pericardium fabric skirt. The leaflets also undergo an anti-calcification treatment using AOA (alpha-amino-oleic acid). The CoreValve is currently available in 4 sizes $(23,26,29,31 \mathrm{~mm})$ and can be implanted in native annuli with diameters ranging from 20 to $29 \mathrm{~mm}$. The valve has received CE mark approval for implantation via the transfemoral, transaxillary/transsubclavian and direct aortic routes.

Instances when a self-expandable devices may be preferable over a balloon-expandable prosthesis include patients with large annuli ( $>27 \mathrm{~mm}$ ), heavy calcification of the aortic annulus/LVOT with an attendant risk of rupture, very low take off of the coronary arteries $(<8 \mathrm{~mm})$, small left ventricular cavity, severely depressed LVEF (since at least one episode of rapid pacing can be omitted), extremely oval-shaped annulus or valve-in-valve procedures with small surgical prostheses [54]. Conversely, a balloonexpandable device may be preferable among patients with a dilated ascending aorta $(>43 \mathrm{~mm})$, a high risk of atrioventricular conduction disturbances (e.g., right bundle branch block on baseline electrocardiogram) or a horizontal ascending aorta (consider transapical approach) [54]. In patients eligible for either prosthesis, choice generally comes down to operator and/or institutional preference. 
Table 3 Current CE mark approved transcatheter heart valve bioprostheses

\begin{tabular}{|c|c|c|c|c|c|c|c|c|}
\hline Device & Manufacturer & Route & $\begin{array}{l}\text { Delivery } \\
\text { site }\end{array}$ & $\begin{array}{l}\text { Mode of } \\
\text { expansion }\end{array}$ & $\begin{array}{l}\text { Valve } \\
\text { material }\end{array}$ & Stent frame & $\begin{array}{l}\text { Sizes, } \\
\mathrm{mm}\end{array}$ & $\begin{array}{l}\text { CE mark } \\
\text { approval }\end{array}$ \\
\hline \multirow[t]{6}{*}{$\begin{array}{l}\text { Medtronic } \\
\text { CoreValve }^{\mathrm{TM}}\end{array}$} & \multirow[t]{6}{*}{$\begin{array}{l}\text { Medtronic, Inc. } \\
\text { Minneapolis, MN }\end{array}$} & $\mathrm{TF}$ & $\begin{array}{l}\text { Native } \\
\text { valve }\end{array}$ & Self-expandable & Porcine & Nitinol & 26,29 & May 2007 \\
\hline & & $\mathrm{TS}$ & & & & & 26,29 & $\begin{array}{l}\text { December } \\
2010\end{array}$ \\
\hline & & TF, TS & & & & & 31 & August 2011 \\
\hline & & DA & & & & & $26,29,31$ & $\begin{array}{l}\text { November } \\
2011\end{array}$ \\
\hline & & $\begin{array}{l}\text { TF, TS, } \\
\text { DA }\end{array}$ & & & & & 23 & $\begin{array}{l}\text { September } \\
2012\end{array}$ \\
\hline & & $\begin{array}{l}\text { TF, TS, } \\
\text { DA }\end{array}$ & $\begin{array}{l}\text { Valve-in- } \\
\text { valve }\end{array}$ & & & & $\begin{array}{l}23,26 \\
29,31\end{array}$ & May 2013 \\
\hline \multirow[t]{3}{*}{$\begin{array}{l}\text { Edwards SAPIEN } \\
\text { XT }^{\mathrm{TM}}\end{array}$} & \multirow[t]{3}{*}{$\begin{array}{l}\text { Edwards Lifesciences Inc., } \\
\text { CA, USA }\end{array}$} & TF,TA & $\begin{array}{l}\text { Native } \\
\text { valve }\end{array}$ & $\begin{array}{l}\text { Balloon- } \\
\text { expandable }\end{array}$ & Bovine & $\begin{array}{l}\text { Cobalt } \\
\text { chromium }\end{array}$ & 23,26 & March 2010 \\
\hline & & TA & & & & & 29 & March 2011 \\
\hline & & $\mathrm{TF}$ & & & & & 29 & May 2012 \\
\hline $\begin{array}{l}\text { Edwards SAPIEN } \\
3^{\mathrm{TM}}\end{array}$ & $\begin{array}{l}\text { Edwards Lifesciences Inc., } \\
\text { CA, USA }\end{array}$ & $\mathrm{TF}$ & $\begin{array}{l}\text { Native } \\
\text { valve }\end{array}$ & $\begin{array}{l}\text { Balloon- } \\
\text { expandable }\end{array}$ & Bovine & $\begin{array}{l}\text { Cobalt } \\
\text { chromium }\end{array}$ & 26 & $\begin{array}{l}\text { January } \\
2014\end{array}$ \\
\hline $\begin{array}{l}\text { Symetis Acurate } \\
\mathrm{TA}^{\mathrm{TM}}\end{array}$ & $\begin{array}{l}\text { Symetis SA, Ecublens, } \\
\text { Switzerland }\end{array}$ & TA & $\begin{array}{l}\text { Native } \\
\text { valve }\end{array}$ & Self-expandable & Porcine & Nitinol & $23,25,27$ & $\begin{array}{l}\text { September } \\
2011\end{array}$ \\
\hline JenaValve ${ }^{\mathrm{TM}}$ & $\begin{array}{l}\text { JenaValve, Munich, } \\
\text { Germany }\end{array}$ & TA & $\begin{array}{l}\text { Native } \\
\text { valve }\end{array}$ & Self-expandable & Porcine & Nitinol & $23,25,27$ & $\begin{array}{l}\text { September } \\
2011^{\mathrm{a}}\end{array}$ \\
\hline \multirow[t]{2}{*}{ St. Jude Portico ${ }^{\mathrm{TM}}$} & \multirow[t]{2}{*}{$\begin{array}{l}\text { St. Jude Medical Inc., MN, } \\
\text { USA }\end{array}$} & $\mathrm{TF}$ & $\begin{array}{l}\text { Native } \\
\text { valve }\end{array}$ & Self-expandable & Bovine & Nitinol & 23 & $\begin{array}{l}\text { November } \\
2012\end{array}$ \\
\hline & & $\mathrm{TF}$ & & & & & 25 & $\begin{array}{l}\text { December } \\
2013\end{array}$ \\
\hline \multirow[t]{2}{*}{ Direct Flow Medical } & \multirow[t]{2}{*}{$\begin{array}{l}\text { Direct Flow Medical, Santa } \\
\text { Rosa, CA }\end{array}$} & $\mathrm{TF}$ & $\begin{array}{l}\text { Native } \\
\text { valve }\end{array}$ & Polymerization & Bovine & Polymer & 25,27 & $\begin{array}{l}\text { January } \\
2013\end{array}$ \\
\hline & & $\mathrm{TF}$ & & & & & 29 & $\begin{array}{l}\text { January } \\
2014\end{array}$ \\
\hline $\begin{array}{l}\text { Medtronic } \\
\text { Engager }^{\mathrm{TM}}\end{array}$ & $\begin{array}{l}\text { Medtronic, Inc. } \\
\text { Minneapolis, MN }\end{array}$ & TA & $\begin{array}{l}\text { Native } \\
\text { valve }\end{array}$ & Self-expandable & Bovine & Nitinol & 23 & $\begin{array}{l}\text { February } \\
2013\end{array}$ \\
\hline $\begin{array}{l}\text { Sadra Medical } \\
\text { Lotus }^{\mathrm{TM}} \text { valve }\end{array}$ & $\begin{array}{l}\text { Boston Scientific Inc., MN, } \\
\text { USA }\end{array}$ & $\mathrm{TF}$ & $\begin{array}{l}\text { Native } \\
\text { valve }\end{array}$ & $\begin{array}{l}\text { Unique expansion } \\
\text { mechanism }^{\mathrm{b}}\end{array}$ & Bovine & Nitinol & 23,27 & $\begin{array}{l}\text { October } \\
2013\end{array}$ \\
\hline
\end{tabular}

CE mark approved devices as of January 2014, TF transfemoral, $T S$ transsubclavian, DA direct aortic

${ }^{\mathrm{a}}$ In September 2013, JenaValve ${ }^{\mathrm{TM}}$ received CE mark approval for the treatment of aortic regurgitation

b The Lotus valve expands in the native annulus as it shortens (the "Chinese finger trap" principle)

\section{Access}

The transfemoral route is generally considered the default approach when feasible as it is least invasive. The fact that transfemoral TAVI can be performed as a completely percutaneous procedure in a consciously sedated patient under local anesthesia has resulted in shorter procedural times, shorter length of hospital stay and earlier mobilization $[55,56]$. Concerns with this approach relate mainly to vascular complications, which have been shown to have an adverse impact on clinical outcomes [57]. In the FRANCE 2 registry $(n=3,195)$, three quarters of patients underwent TAVI via the transfemoral route [58]. Advantages with the transapical approach include a low risk of peripheral vascular injury, a direct pathway to the aortic valve, and easier antegrade crossing of the aortic valve [59]. Problems relate to direct myocardial injury, bleeding, injury to the mitral valve apparatus, hemodynamic instability, need for orotracheal intubation, post-operative respiratory compromise and thoracotomy pain [59]. Among patients with unfavorable iliofemoral anatomy, the Medtonic CoreValve can be inserted via the transaxillary/ transsubclavian route [60]. In the absence of calcification, the minimum artery diameter should be at least $6 \mathrm{~mm}$ for an $18 \mathrm{~F}$ sheath but in patients with a patent left internal mammary artery graft, the diameter should be $\geq 7.5 \mathrm{~mm}$ in order not to obstruct flow to the graft [61]. Normally, a surgical cut-down is performed, but a fully percutaneous procedure has been described [62,63]. The direct aortic approach can be performed via a small right upper "J" hemisternotomy or a small right anterior thoracotomy and has become increasingly popular for implantation of both the Medtronic CoreValve and the Edwards SAPIEN devices [64]. Advantages with the direct aortic approach 
include direct access to a large-calibre vessel, thereby avoiding smaller arteries like the iliofemoral or subclavian artery, a more direct pathway to the aortic valve and an operating technique familiar to surgeons [54].

Different sheath sizes are available depending on the size and make of the transcatheter heart valve prosthesis and access route chosen. For the transfemoral route, the Edwards e-Sheath, used with the NovaFlex + delivery system (Edwards Lifesciences, Inc., Irvine, CA, USA), comes in $16 \mathrm{~F}, 18 \mathrm{~F}$ and $20 \mathrm{~F}$ for the 20 and $23 \mathrm{~mm}(16 \mathrm{~F})$, $26 \mathrm{~mm}(18 \mathrm{~F})$ and $29 \mathrm{~mm}(20 \mathrm{~F})$ Edwards SAPIEN XT THV, respectively. The e-Sheath has a Dynamic Expansion Mechanism enabling temporary expansion of the sheath during passage of the transcatheter heart valve before resuming its unexpanded shape. Minimal femoral artery diameters are $6 \mathrm{~mm}$ for the $20 \mathrm{~mm}$ and $23 \mathrm{~mm}$ SAPIEN XT, $6.5 \mathrm{~mm}$ for the $26 \mathrm{~mm}$ SAPIEN XT and $7.0 \mathrm{~mm}$ for the $29 \mathrm{~mm}$ SAPIEN XT prostheses, respectively (Table 2). The ASCENDRA-II ${ }^{\mathrm{TM}}$ system (Edwards Lifesciences, Inc., Irvine, CA, USA), used for the transapical approach, requires the use of either a $24 \mathrm{~F}$ (23 and $26 \mathrm{~mm}$ SAPIEN XT) or a 26F (29 mm SAPIEN XT) introducer sheath.

In the current iteration of the Medtronic CoreValve system, the $18 \mathrm{~F}$ introducer sheath is not supplied. Available sheaths for use with this system include the Check-Flo ${ }^{\mathrm{TM}}$ sheath (Cook Medical Inc., Bloomington, IN, USA), Ultimum $^{\text {TM }}$ sheath (St. Jude Medical, Inc., St. Paul, MN, USA) Gore DrySeal ${ }^{\mathrm{TM}}$ Sheath (Gore Medical Inc., AZ, USA) or the SoloPath ${ }^{\mathrm{TM}}$ sheath (Onset Medical Corp. CA, USA). The latter is a $14 \mathrm{~F}$ expandable sheath and can be

Table 4 Introducer sheaths used with the Medtronic CoreValve

\begin{tabular}{|c|c|c|c|}
\hline Manufacturer & Sheath & $\begin{array}{l}\text { Internal } \\
\text { diameter } \\
(\text { French*) }\end{array}$ & $\begin{array}{l}\text { External } \\
\text { diameteı } \\
(\mathrm{mm})\end{array}$ \\
\hline $\begin{array}{l}\text { Cook Medical Inc., } \\
\text { Bloomington, } \\
\text { IN, USA }\end{array}$ & $\begin{array}{l}\text { Check-Flo }^{\mathrm{TM}} \\
\text { introducer }\end{array}$ & 18 & 7.2 \\
\hline \multirow{3}{*}{$\begin{array}{l}\text { St. Jude Medical, } \\
\text { Inc., St. Paul, } \\
\text { MN, USA }\end{array}$} & \multirow[t]{3}{*}{ Ultimum $^{\mathrm{TM}}$} & 18 & 6.8 \\
\hline & & 19 & 7.6 \\
\hline & & 21 & 8.2 \\
\hline \multirow{3}{*}{$\begin{array}{l}\text { Onset Medical } \\
\text { Corp. CA, USA }\end{array}$} & \multirow{3}{*}{$\begin{array}{l}\text { SoloPathTM } \\
\text { balloon } \\
\text { expandable } \\
\text { transfemoral } \\
\text { introducer }\end{array}$} & 18 & 7.3 \\
\hline & & 19 & 7.7 \\
\hline & & 21 & 8 \\
\hline \multirow{3}{*}{$\begin{array}{l}\text { Gore Medical } \\
\text { Inc., AZ, USA }\end{array}$} & \multirow[t]{3}{*}{ DrySheath $^{\mathrm{TM}}$} & 16 & 6.2 \\
\hline & & 18 & 6.8 \\
\hline & & 20 & 7.5 \\
\hline
\end{tabular}

* French size $=3 \times$ internal diameter in $\mathrm{mm}$. Therefore, $18 \mathrm{~F}=6 \mathrm{~mm}$, etc dilated to over $18 \mathrm{~F}$ with a balloon once introduced into the artery, theoretically reducing the risk of arterial injury during sheath insertion [65]. Sheath dimensions and minimal vascular dimensions are shown in Table 4.

\section{Prevention of complications}

Meticulous pre-procedural planning can minimize the occurrence of complications. Vascular complications remain an important concern with TAVI [57]. Using the large diameter $22 \mathrm{~F}$ and $24 \mathrm{~F}$ RetroFlex delivery system, the incidence of major vascular complications was 10.6, 11.0 and $16.2 \%$ in the Edwards SAPIEN Aortic Bioprosthesis European Outcome (SOURCE) registry and PARTNER IA \& B trials, respectively [20, 66, 67]. Using the lower profile NovaFlex delivery systems, the SOURCE XT registry recently reported a reduced major vascular complication rate of $7.5 \%$ [68]. In addition, the PARTNER 2B trial revealed that "inoperable" patients undergoing TAVI with the newer generation SAPIEN XT and NovaFlex delivery system $(18 \mathrm{~F}$ and $19 \mathrm{~F})$ had a significantly lower rate of major vascular complications as compared with those undergoing TAVI with the earlier generation SAPIEN and RetroFlex 3 delivery system (22F and 24F) (9.6 vs $15.5 \%$, $p=0.04$ ) [69]. This was mainly driven by reductions in vascular perforations and dissections in the SAPIEN XT cohort [69]. In addition to the use of smaller sheaths, angiographic and computed tomographic screening and patient selection have also been shown to reduce vascular complications [24]. Therefore, rigorous screening of the peripheral vessels is essential. Stroke has emerged as an important consideration. Major stroke was reported at a rate of 3.8 and $5.0 \%$ in the PARTNER A and B cohorts, respectively [20,67]. Predictors of cerebrovascular events included prior stroke, smaller indexed aortic valve area, higher NYHA functional class and transapical access [70]. An increased risk of neurological events was observed in both SAVR and TAVI groups during the course of the first week, but there was no subsequent increased risk over SAVR up until 2 years [70]. Strategies suggested to reduce the acute stroke rate include omitting balloon aortic valvuloplasty, minimizing the passage of guide wires and catheters across the aortic arch and the use of embolic protection devices. Atrioventricular conduction disturbances requiring permanent pacemaker (PPM) insertion are more frequent after TAVI than after SAVR with the use of self-expanding Medtronic CoreValve prosthesis but not with the balloon-expandable SAPIEN valve [20]. Mechanical trauma to the left bundle branch or His bundle located near the subannular membranous septum may be responsible [71]. Predictors of PPM insertion include preexisting RBBB, balloon pre-dilatation, and prolonged QRS duration [72]. A recent study reported that survival up to 
Table 5 Devices pending CE mark approval

\begin{tabular}{|c|c|c|c|c|c|c|}
\hline Device & Manufacturer & Route & Mode of expansion & $\begin{array}{l}\text { Valve } \\
\text { material }\end{array}$ & Stent frame & Sizes \\
\hline Edwards SAPIEN XT ${ }^{\mathrm{TM}}$ & $\begin{array}{l}\text { Edwards Lifesciences Inc., CA, } \\
\text { USA }\end{array}$ & $\begin{array}{l}\text { TF, TA, } \\
\text { DA }\end{array}$ & Balloon-expandable & Bovine & $\begin{array}{l}\text { Cobalt } \\
\text { chromium }\end{array}$ & 20 \\
\hline Edwards CENTERA $^{\mathrm{TM}}$ & $\begin{array}{l}\text { Edwards Lifesciences Inc., CA, } \\
\text { USA }\end{array}$ & TF, TAx & $\begin{array}{l}\text { Self-expandable } \\
\quad \text { (motorized system) }\end{array}$ & Bovine & Nitinol & 26 \\
\hline $\begin{array}{l}\text { Medtronic CoreValve } \\
\text { Evolut } \mathrm{R}^{\mathrm{TM}}\end{array}$ & $\begin{array}{l}\text { Medtronic, Minneapolis, MN, } \\
\text { USA }\end{array}$ & $\begin{array}{l}\text { TF, TA, } \\
\text { DA }\end{array}$ & Self-expandable & Porcine & Nitinol & $\begin{array}{l}23,26,29, \\
31\end{array}$ \\
\hline $\begin{array}{l}\text { Symetis ACURATE } \\
\mathrm{TF}^{\mathrm{TM}}\end{array}$ & $\begin{array}{l}\text { Symetis SA, Ecublens, } \\
\text { Switzerland }\end{array}$ & $\mathrm{TF}$ & Self-expandable & Porcine & Nitinol & $23,25,27$ \\
\hline NVT ALLEGRA $^{\mathrm{TM}}$ & $\begin{array}{l}\text { New valve technology, Muri, } \\
\text { Switzerland }\end{array}$ & $\mathrm{TF}$ & Self-expandable & Bovine & Nitinol & $23,27,31$ \\
\hline INOVARE $^{\mathrm{TM}}$ & $\begin{array}{l}\text { Braile Biomèdica, São José do } \\
\text { Rio Preto, Brazil }\end{array}$ & TA & Balloon-expandable & Bovine & $\begin{array}{l}\text { Stainless } \\
\text { steel }^{\mathrm{a}}\end{array}$ & $\begin{array}{c}20,22,24, \\
26,28\end{array}$ \\
\hline
\end{tabular}

Devices pending CE mark approval as of January 2014

$N V T$ new valve technologies

${ }^{\text {a }}$ Cobalt chromium version now available also

1-year follow-up was not worse among patients requiring a PPM after TAVI, but the long-term effects of right ventricular pacing remain unknown [73]. Paravalvular regurgitation is the result of prosthesis undersizing, malpositioning or malapposition secondary to excessive or asymmetric calcification [41, 74]. Moderate or severe paravalvular regurgitation at 30 days was reported in 12.2 and $11.8 \%$ of patients after TAVI in the PARTNER A \& B cohorts, respectively, as compared with just $0.9 \%$ in the PARTNER A SAVR cohort [20, 67]. Several studies have shown that moderate or severe paravalvular regurgitation is associated with impaired prognosis after TAVI [75, 76] Accurate annular measurements are important to avoid undersizing, and multimodality imaging can help assess the extent and location of calcification.

\section{Future perspectives}

Further refinements in patient selection and technological improvements in transcatheter delivery systems and bioprostheses are anticipated in the future. Several new transcatheter heart valve prostheses are in the pipeline (Table 5). Improved methods of patient risk stratification are required and ideally a dedicated "TAVI risk score" should be developed and validated in a large population of TAVI patients. Further downsizing of the introducer sheath may reduce the incidence of vascular complications. For example, the newer generation Edwards SAPIEN $3^{\mathrm{TM}}$ (Edwards Lifesciences, Inc., Irvine, CA, USA) can be introduced via a $14 \mathrm{~F}$ introducer sheath using the Commander $^{\mathrm{TM}}$ delivery system (Edwards Lifesciences, Inc., Irvine, CA, USA) [77]. The Medtronic CoreValve
Evolut $\mathrm{R}^{\mathrm{TM}}$ (Medtronic, Minneapolis, MN, USA) will be delivered via the EnVeo $\mathrm{R}$ delivery system, which also has a $14 \mathrm{~F}$ inner diameter. In addition, percutaneous closure systems with reliable performance are needed. The incidence of paravalvular aortic regurgitation may be reduced by the development of completely repositionable and retrievable devices to immediately correct malpositioning. This is now possible with several newer generation THV bioprostheses, including the St. Jude Medical Portico $^{\text {TM }}$ (St. Jude Medical, St. Paul, Minnesota), and Sadra Medical Lotus ${ }^{\mathrm{TM}}$ (Boston Scientific, Natick, Massachusetts) bioprostheses. In addition, newer generation THV bioprostheses such as the Edwards SAPIEN $3^{\mathrm{TM}}$ (Edwards Lifesciences, Inc., Irvine, CA, USA) have unique sealing mechanisms to further reduce paravalvular aortic regurgitation. Other refinements needed are mechanisms to reduce stroke risk and heart block. TAVI has already been performed in lower risk patients and clinical outcomes are in fact better [78]. The extension of TAVI to intermediate-risk patients is currently the subject of the ongoing SURTAVI and PARTNER 2A randomized clinical trials. Further data on long-term valve durability are also required.

\section{Conclusions}

The success of TAVI over the past decade can be attributed in large part to the rigorous preinterventional screening of clinical and anatomical patient characteristics and to the multidisciplinary collaborative approach in selecting the most appropriate patients for this procedure. Multimodality imaging has also played a role. Further refinements in risk 
stratification and technological advancements in transcatheter heart valves and delivery systems should lead to lower complication rates and improved clinical outcomes in the future.

Conflicts of interest S.W. has received honoraria and consultant fees from Edwards LifeSciences and Medtronic. P.W. is proctor and receives honoraria from Medtronic and Edwards LifeSciences. L.B. is a consultant and proctor for Medtronic and Edwards LifeSciences. All other authors have no relationships relevant to the contents of this paper to disclose.

\section{References}

1. Makkar RR, Fontana GP, Jilaihawi H, Kapadia S, Pichard AD, Douglas PS, Thourani VH, Babaliaros VC, Webb JG, Herrmann HC, Bavaria JE, Kodali S, Brown DL, Bowers B, Dewey TM, Svensson LG, Tuzcu M, Moses JW, Williams MR, Siegel RJ, Akin JJ, Anderson WN, Pocock S, Smith CR, Leon MB (2012) Transcatheter aortic-valve replacement for inoperable severe aortic stenosis. N Engl J Med 366:1696-1704

2. Kodali SK, Williams MR, Smith CR, Svensson LG, Webb JG, Makkar RR, Fontana GP, Dewey TM, Thourani VH, Pichard AD, Fischbein M, Szeto WY, Lim S, Greason KL, Teirstein PS, Malaisrie SC, Douglas PS, Hahn RT, Whisenant B, Zajarias A, Wang D, Akin JJ, Anderson WN, Leon MB (2012) Two-year outcomes after transcatheter or surgical aortic-valve replacement. N Engl J Med 366:1686-1695

3. Piazza N, Lange R, Martucci G, Serruys PW (2012) Patient selection for transcatheter aortic valve implantation: patient risk profile and anatomical selection criteria. Arch Cardiovasc Dis 105:165-173

4. Vahanian A, Alfieri O, Andreotti F, Antunes MJ, Baron-Esquivias G, Baumgartner H, Borger MA, Carrel TP, De Bonis M, Evangelista A, Falk V, Iung B, Lancellotti P, Pierard L, Price S, Schafers HJ, Schuler G, Stepinska J, Swedberg K, Takkenberg J, Von Oppell UO, Windecker S, Zamorano JL, Zembala M (2012) Guidelines on the management of valvular heart disease (version 2012). Eur Heart J 33:2451-2496

5. Rosenhek R, Iung B, Tornos P, Antunes MJ, Prendergast BD, Otto CM, Kappetein AP, Stepinska J, Kaden JJ, Naber CK, Acarturk E, Gohlke-Barwolf C (2012) Esc working group on valvular heart disease position paper: assessing the risk of interventions in patients with valvular heart disease. Eur Heart J.33:822-828, 828a, 828b

6. Mack MJ (2011) Risk scores for predicting outcomes in valvular heart disease: How useful? Curr Cardiol Rep 13:107-112

7. Bloomfield GS, Gillam LD, Hahn RT, Kapadia S, Leipsic J, Lerakis S, Tuzcu M, Douglas PS (2012) A practical guide to multimodality imaging of transcatheter aortic valve replacement. JACC Cardiovasc Imaging 5:441-455

8. Piazza N, de Jaegere P, Schultz C, Becker AE, Serruys PW, Anderson RH (2008) Anatomy of the aortic valvar complex and its implications for transcatheter implantation of the aortic valve. Circ Cardiovasc Interv 1:74-81

9. Webb J, Rodes-Cabau J, Fremes S, Pibarot P, Ruel M, Ibrahim R, Welsh R, Feindel C, Lichtenstein S (2012) Transcatheter aortic valve implantation: a Canadian Cardiovascular Society position statement. Can J Cardiol 28:520-528

10. Toggweiler S, Humphries KH, Lee M, Binder RK, Moss RR, Freeman M, Ye J, Cheung A, Wood DA, Webb JG (2013) 5-year outcome after transcatheter aortic valve implantation. J Am Coll Cardiol 61:413-419
11. Nashef SA, Roques F, Michel P, Gauducheau E, Lemeshow S, Salamon R (1999) European system for cardiac operative risk evaluation (euroscore). Eur J Cardio-Thorac Surg Off J Eur Assoc Cardio-Thorac Surg 16:9-13

12. Roques F, Michel P, Goldstone AR, Nashef SA (2003) The logistic euroscore. Eur Heart J 24:881-882

13. O'Brien SM, Shahian DM, Filardo G, Ferraris VA, Haan CK, Rich JB, Normand SL, DeLong ER, Shewan CM, Dokholyan RS, Peterson ED, Edwards FH, Anderson RP (2009) The society of thoracic surgeons 2008 cardiac surgery risk models part 2: isolated valve surgery. Ann Thorac Surg 88:S23-S42

14. Nashef SA, Roques F, Sharples LD, Nilsson J, Smith C, Goldstone AR, Lockowandt U (2012) Euroscore ii. Eur J CardioThorac Surg Off J Eur Assoc Cardio-Thorac Surg 41:734-744 discussion 744-735

15. Ambler G, Omar RZ, Royston P, Kinsman R, Keogh BE, Taylor KM (2005) Generic, simple risk stratification model for heart valve surgery. Circulation 112:224-231

16. Kotting J, Schiller W, Beckmann A, Schafer E, Dobler K, Hamm C, Veit C, Welz A (2013) German aortic valve score: a new scoring system for prediction of mortality related to aortic valve procedures in adults. Eur J Cardio-Thorac Surg Off J Eur Assoc Cardio-Thorac Surg 43:971-977

17. Nowicki ER, Birkmeyer NJ, Weintraub RW, Leavitt BJ, Sanders JH, Dacey LJ, Clough RA, Quinn RD, Charlesworth DC, Sisto DA, Uhlig PN, Olmstead EM, O'Connor GT (2004) Multivariable prediction of in-hospital mortality associated with aortic and mitral valve surgery in northern New England. Ann Thorac Surg 77:1966-1977

18. Hannan EL, Wu C, Bennett EV, Carlson RE, Culliford AT, Gold JP, Higgins RS, Smith CR, Jones RH (2007) Risk index for predicting in-hospital mortality for cardiac valve surgery. Ann Thorac Surg 83:921-929

19. Jin R, Grunkemeier GL, Starr A (2005) Validation and refinement of mortality risk models for heart valve surgery. Ann Thorac Surg 80:471-479

20. Smith CR, Leon MB, Mack MJ, Miller DC, Moses JW, Svensson LG, Tuzcu EM, Webb JG, Fontana GP, Makkar RR, Williams M, Dewey T, Kapadia S, Babaliaros V, Thourani VH, Corso P, Pichard AD, Bavaria JE, Herrmann HC, Akin JJ, Anderson WN, Wang D, Pocock SJ (2011) Transcatheter versus surgical aorticvalve replacement in high-risk patients. $\mathrm{N}$ Engl $\mathrm{J}$ Med 364:2187-2198

21. Durand E, Borz B, Godin M, Tron C, Litzler PY, Bessou JP, Dacher JN, Bauer F, Cribier A, Eltchaninoff H (2013) Performance analysis of euroscore ii compared to the original logistic euroscore and sts scores for predicting 30-day mortality after transcatheter aortic valve replacement. Am J Cardiol 111: 891-897

22. Sedaghat A, Sinning JM, Vasa-Nicotera M, Ghanem A, Hammerstingl C, Grube E, Nickenig G, Werner N (2013) The revised euroscore ii for the prediction of mortality in patients undergoing transcatheter aortic valve implantation. Clin Res Cardiol Off J Ger Cardiac Soc

23. Hayashida K, Lefevre T, Chevalier B, Hovasse T, Romano M, Garot P, Mylotte D, Uribe J, Farge A, Donzeau-Gouge P, Bouvier E, Cormier B, Morice MC (2011) Transfemoral aortic valve implantation new criteria to predict vascular complications. JACC Cardiovasc Interv 4:851-858

24. Toggweiler S, Gurvitch R, Leipsic J, Wood DA, Willson AB, Binder RK, Cheung A, Ye J, Webb JG (2012) Percutaneous aortic valve replacement: vascular outcomes with a fully percutaneous procedure. J Am Coll Cardiol 59:113-118

25. Eltchaninoff H, Kerkeni M, Zajarias A, Tron C, Godin M, Sanchez Giron C, Baala B, Cribier A (2009) Aorto-iliac angiography as a screening tool in selecting patients for transfemoral aortic 
valve implantation with the edwards sapien bioprosthesis. EuroInterv J EuroPCR Collab Work Gr Interv Cardiol Eur Soc Cardiol 5:438-442

26. Achenbach S, Delgado V, Hausleiter J, Schoenhagen P, Min JK, Leipsic JA (2012) Scct expert consensus document on computed tomography imaging before transcatheter aortic valve implantation (tavi)/transcatheter aortic valve replacement (tavr). J Cardiovasc Comput Tomogr 6:366-380

27. de Vaan J, Verstraeten L, de Jaegere P, Schultz C (2012) The 3 mensio valves multimodality workstation. EuroInterv J EuroPCR Collab Work Gr Interv Cardiol Eur Soc Cardiol 7:1464-1469

28. Wenaweser P, Windecker S (2010) Anatomical suitability for transcatheter aortic valve implantation with complementary roles for 2 rivals. JACC Cardiovasc Interv 3:867-869

29. Kasel AM, Cassese S, Bleiziffer S, Amaki M, Hahn RT, Kastrati A, Sengupta PP (2013) Standardized imaging for aortic annular sizing: implications for transcatheter valve selection. JACC Cardiovasc Imaging 6:249-262

30. Barbanti M, Yang TH, Rodes Cabau J, Tamburino C, Wood DA, Jilaihawi H, Blanke P, Makkar RR, Latib A, Colombo A, Tarantini G, Raju R, Binder RK, Nguyen G, Freeman M, Ribeiro HB, Kapadia S, Min J, Feuchtner G, Gurtvich R, Alqoofi F, Pelletier M, Ussia GP, Napodano M, De Brito FS Jr, Kodali S, Norgaard BL, Hansson NC, Pache G, Canovas SJ, Zhang H, Leon MB, Webb JG, Leipsic J (2013) Anatomical and procedural features associated with aortic root rupture during balloonexpandable transcatheter aortic valve replacement. Circulation 128:244-253

31. Zamorano JL, Badano LP, Bruce C, Chan KL, Goncalves A, Hahn RT, Keane MG, La Canna G, Monaghan MJ, Nihoyannopoulos P, Silvestry FE, Vanoverschelde JL, Gillam LD (2011) Eae/ase recommendations for the use of echocardiography in new transcatheter interventions for valvular heart disease. Eur Heart $\mathbf{J}$ 32:2189-2214

32. Buellesfeld L, Stortecky S, Kalesan B, Gloekler S, Khattab AA, Nietlispach F, Delfine V, Huber C, Eberle B, Meier B, Wenaweser P, Windecker S (2013) Aortic root dimensions among patients with severe aortic stenosis undergoing transcatheter aortic valve replacement. JACC Cardiovasc Interv 6:72-83

33. Schultz CJ, Moelker A, Piazza N, Tzikas A, Otten A, Nuis RJ, Neefjes LA, van Geuns RJ, de Feyter P, Krestin G, Serruys PW, de Jaegere PP (2010) Three dimensional evaluation of the aortic annulus using multislice computer tomography: are manufacturer's guidelines for sizing for percutaneous aortic valve replacement helpful? Eur Heart J 31:849-856

34. Gurvitch R, Webb JG, Yuan R, Johnson M, Hague C, Willson AB, Toggweiler S, Wood DA, Ye J, Moss R, Thompson CR, Achenbach S, Min JK, Labounty TM, Cury R, Leipsic J (2011) Aortic annulus diameter determination by multidetector computed tomography: reproducibility, applicability, and implications for transcatheter aortic valve implantation. JACC Cardiovasc Interv 4:1235-1245

35. Jilaihawi H, Kashif M, Fontana G, Furugen A, Shiota T, Friede G, Makhija R, Doctor N, Leon MB, Makkar RR (2012) Crosssectional computed tomographic assessment improves accuracy of aortic annular sizing for transcatheter aortic valve replacement and reduces the incidence of paravalvular aortic regurgitation. J Am Coll Cardiol 59:1275-1286

36. Wessely M, Rau S, Lange P, Kehl K, Renz V, Schonermarck U, Steinbeck G, Fischereder M, Boekstegers P (2012) Chronic kidney disease is not associated with a higher risk for mortality or acute kidney injury in transcatheter aortic valve implantation. Nephrol Dial Transplantat Off Publ Eur Dial Transpl Assoc Eur Renal Assoc 27:3502-3508

37. Willson AB, Webb JG, Labounty TM, Achenbach S, Moss R, Wheeler M, Thompson C, Min JK, Gurvitch R, Norgaard BL,
Hague CJ, Toggweiler S, Binder R, Freeman M, Poulter R, Poulsen S, Wood DA, Leipsic J (2012) 3-dimensional aortic annular assessment by multidetector computed tomography predicts moderate or severe paravalvular regurgitation after transcatheter aortic valve replacement: a multicenter retrospective analysis. J Am Coll Cardiol 59:1287-1294

38. Binder RK, Webb JG, Willson AB, Urena M, Hansson NC, Norgaard BL, Pibarot P, Barbanti M, Larose E, Freeman M, Dumont E, Thompson C, Wheeler M, Moss RR, Yang TH, Pasian S, Hague CJ, Nguyen G, Raju R, Toggweiler S, Min JK, Wood DA, Rodes-Cabau J, Leipsic J (2013) The impact of integration of a multidetector computed tomography annulus area sizing algorithm on outcomes of transcatheter aortic valve replacement: a prospective, multicenter, controlled trial. J Am Coll Cardiol 62:431-438

39. Hamdan A, Guetta V, Konen E, Goitein O, Segev A, Raanani E, Spiegelstein D, Hay I, Di Segni E, Eldar M, Schwammenthal E (2012) Deformation dynamics and mechanical properties of the aortic annulus by 4-dimensional computed tomography: insights into the functional anatomy of the aortic valve complex and implications for transcatheter aortic valve therapy. J Am Coll Cardiol 59:119-127

40. O'Sullivan CJ, Windecker S (2013) Implications of bicuspid aortic valves for transcatheter aortic valve implantation. Circ Cardiovasc Interv 6:204-206

41. Genereux P, Head SJ, Hahn R, Daneault B, Kodali S, Williams MR, van Mieghem NM, Alu MC, Serruys PW, Kappetein AP, Leon MB (2013) Paravalvular leak after transcatheter aortic valve replacement: the new achilles' heel? A comprehensive review of the literature. J Am Coll Cardiol 61:1125-1136

42. Al-Lamee R, Godino C, Colombo A (2011) Transcatheter aortic valve implantation: current principles of patient and technique selection and future perspectives. Circu Cardiovasc Interv 4:387-395

43. Goel SS, Ige M, Tuzcu EM, Ellis SG, Stewart WJ, Svensson LG, Lytle BW, Kapadia SR (2013) Severe aortic stenosis and coronary artery disease-implications for management in the transcatheter aortic valve replacement era: a comprehensive review. J Am Coll Cardiol 62:1-10

44. Wenaweser P, Pilgrim T, Guerios E, Stortecky S, Huber C, Khattab AA, Kadner A, Buellesfeld L, Gloekler S, Meier B, Carrel T, Windecker S (2011) Impact of coronary artery disease and percutaneous coronary intervention on outcomes in patients with severe aortic stenosis undergoing transcatheter aortic valve implantation. EuroInterv J EuroPCR Collab Work Gr Interv Cardiol Eur Soc Cardiol 7:541-548

45. Pilgrim T, Wenaweser P, Meuli F, Huber C, Stortecky S, Seiler C, Zbinden S, Meier B, Carrel T, Windecker S (2011) Clinical outcome of high-risk patients with severe aortic stenosis and reduced left ventricular ejection fraction undergoing medical treatment or tavi. PLoS One 6:e27556

46. Connolly HM, Oh JK, Orszulak TA, Osborn SL, Roger VL, Hodge DO, Bailey KR, Seward JB, Tajik AJ (1997) Aortic valve replacement for aortic stenosis with severe left ventricular dysfunction. Progn Indic Circ 95:2395-2400

47. Pibarot P, Dumesnil JG (2012) Low-flow, low-gradient aortic stenosis with normal and depressed left ventricular ejection fraction. J Am Coll Cardiol 60:1845-1853

48. Tribouilloy C, Levy F, Rusinaru D, Gueret P, Petit-Eisenmann H, Baleynaud S, Jobic Y, Adams C, Lelong B, Pasquet A, Chauvel C, Metz D, Quere JP, Monin JL (2009) Outcome after aortic valve replacement for low-flow/low-gradient aortic stenosis without contractile reserve on dobutamine stress echocardiography. J Am Coll Cardiol 53:1865-1873

49. Herrmann HC, Pibarot P, Hueter I, Gertz ZM, Stewart WJ, Kapadia S, Tuzcu EM, Babaliaros V, Thourani V, Szeto WY, 
Bavaria JE, Kodali S, Hahn RT, Williams M, Miller DC, Douglas PS, Leon MB (2013) Predictors of mortality and outcomes of therapy in low-flow severe aortic stenosis: a placement of aortic transcatheter valves (partner) trial analysis. Circulation 127:2316-2326

50. O'Sullivan CJ, Stortecky S, Heg D, Pilgrim T, Hosek N, Buellesfeld L, Khattab AA, Nietlispach F, Moschovitis A, Zanchin T, Meier B, Windecker S, Wenaweser P (2013) Clinical outcomes of patients with low-flow, low-gradient, severe aortic stenosis and either preserved or reduced ejection fraction undergoing transcatheter aortic valve implantation. Eur Heart $\mathbf{J}$ 34:3437-3450

51. Hachicha Z, Dumesnil JG, Bogaty P, Pibarot P (2007) Paradoxical low-flow, low-gradient severe aortic stenosis despite preserved ejection fraction is associated with higher afterload and reduced survival. Circulation 115:2856-2864

52. O'Sullivan CJ, Stortecky S, Wenaweser P (2013) Invasive hemodynamic assessment of "paradoxical" low-flow severe aortic stenosis. J Am Coll Cardiol 62:1492-1493

53. Nietlispach F, Wijesinghe N, Wood D, Carere RG, Webb JG (2010) Current balloon-expandable transcatheter heart valve and delivery systems. Catheter Cardiovasc Interv Off J Soc Cardiac Angiogr Interv 75:295-300

54. Stortecky S, Buellesfeld L, Wenaweser P, Windecker S (2012) Transcatheter aortic valve implantation: the procedure. Heart 98(Suppl 4):44-51

55. Motloch LJ, Rottlaender D, Reda S, Larbig R, Bruns M, MullerEhmsen J, Strauch J, Madershahian N, Erdmann E, Wahlers T, Hoppe UC (2012) Local versus general anesthesia for transfemoral aortic valve implantation. Clin Res Cardiol Off J Ger Cardiac Soc 101:45-53

56. Yamamoto M, Meguro K, Mouillet G, Bergoend E, Monin JL, Lim P, Dubois-Rande JL, Teiger E (2013) Effect of local anesthetic management with conscious sedation in patients undergoing transcatheter aortic valve implantation. Am J Cardiol 111:94-99

57. Genereux P, Webb JG, Svensson LG, Kodali SK, Satler LF, Fearon WF, Davidson CJ, Eisenhauer AC, Makkar RR, Bergman GW, Babaliaros V, Bavaria JE, Velazquez OC, Williams MR, Hueter I, Xu K, Leon MB (2012) Vascular complications after transcatheter aortic valve replacement: insights from the partner (placement of aortic transcatheter valve) trial. J Am Coll Cardiol 60:1043-1052

58. Gilard M, Eltchaninoff H, Iung B, Donzeau-Gouge P, Chevreul K, Fajadet J, Leprince P, Leguerrier A, Lievre M, Prat A, Teiger E, Lefevre T, Himbert D, Tchetche D, Carrie D, Albat B, Cribier A, Rioufol G, Sudre A, Blanchard D, Collet F, Dos Santos P, Meneveau N, Tirouvanziam A, Caussin C, Guyon P, Boschat J, Le Breton H, Collart F, Houel R, Delpine S, Souteyrand G, Favereau X, Ohlmann P, Doisy V, Grollier G, Gommeaux A, Claudel JP, Bourlon F, Bertrand B, Van Belle E, Laskar M (2012) Registry of transcatheter aortic-valve implantation in high-risk patients. N Engl J Med 366:1705-1715

59. Webb JG, Wood DA (2012) Current status of transcatheter aortic valve replacement. J Am Coll Cardiol 60:483-492

60. Muensterer A, Mazzitelli D, Ruge H, Wagner A, Hettich I, Piazza N, Lange R, Bleiziffer S (2013) Safety and efficacy of the subclavian access route for tavi in cases of missing transfemoral access. Clin Res Cardiol Off J Ger Cardiac Soc 102:627-636

61. Toggweiler S, Leipsic J, Binder RK, Freeman M, Barbanti M, Heijmen RH, Wood DA, Webb JG (2013) Management of vascular access in transcatheter aortic valve replacement part 1: basic anatomy, imaging, sheaths, wires, and access routes. JACC Cardiovasc Interv 6:643-653

62. Schafer U, Ho Y, Frerker C, Schewel D, Sanchez-Quintana D, Schofer J, Bijuklic K, Meincke F, Thielsen T, Kreidel F, Kuck
KH (2012) Direct percutaneous access technique for transaxillary transcatheter aortic valve implantation: the hamburg sankt georg approach. JACC Cardiovasc Interv 5:477-486

63. van Mieghem NM, Luthen C, Oei F, Schultz C, Ligthart J, Kappetein AP, de Jaegere PP (2012) Completely percutaneous transcatheter aortic valve implantation through transaxillary route: an evolving concept. EuroInterv J EuroPCR Collab Work Gr Interv Cardiol Eur Soc Cardiol 7:1340-1342

64. Ramlawi B, Anaya-Ayala JE, Reardon MJ (2012) Transcatheter aortic valve replacement (tavr): access planning and strategies. Method DeBakey Cardiovasc J 8:22-25

65. Dimitriadis Z, Scholtz W, Faber L, Borgermann J, Kleikamp G, Horstkotte D, Wiemer M (2013) Balloon expandable sheath for transfemoral aortic valve implantation: a viable option for patients with challenging access. J Interv Cardiol 26:84-89

66. Thomas M, Schymik G, Walther T, Himbert D, Lefevre T, Treede $\mathrm{H}$, Eggebrecht H, Rubino P, Colombo A, Lange R, Schwarz RR, Wendler O (2011) One-year outcomes of cohort 1 in the edwards sapien aortic bioprosthesis european outcome (source) registry: the european registry of transcatheter aortic valve implantation using the edwards sapien valve. Circulation 124:425-433

67. Leon MB, Smith CR, Mack M, Miller DC, Moses JW, Svensson LG, Tuzcu EM, Webb JG, Fontana GP, Makkar RR, Brown DL, Block PC, Guyton RA, Pichard AD, Bavaria JE, Herrmann HC, Douglas PS, Petersen JL, Akin JJ, Anderson WN, Wang D, Pocock S (2010) Transcatheter aortic-valve implantation for aortic stenosis in patients who cannot undergo surgery. N Engl J Med 363:1597-1607

68. Windecker S (2013) One-year outcomes from the source xt post approval study. Presented at EuroPCR 2013

69. Leon MB (2013) A randomized evaluation of the sapien xt transcatheter valve system in patients with aortic stenosis who are not candidates for surgery: Partner ii, inoperable cohort. Presented at the American College of Cardiology Scientific Sessions, 10 March 2013

70. Miller DC, Blackstone EH, Mack MJ, Svensson LG, Kodali SK, Kapadia S, Rajeswaran J, Anderson WN, Moses JW, Tuzcu EM, Webb JG, Leon MB, Smith CR (2012) Transcatheter (tavr) versus surgical (avr) aortic valve replacement: occurrence, hazard, risk factors, and consequences of neurologic events in the partner trial. J Thorac Cardiovasc Surg 143(832-843):e813

71. van der Boon RM, Nuis RJ, Van Mieghem NM, Jordaens L, Rodes-Cabau J, van Domburg RT, Serruys PW, Anderson RH, de Jaegere PP (2012) New conduction abnormalities after tavi-frequency and causes. Nat Rev Cardiol 9:454-463

72. Khawaja MZ, Rajani R, Cook A, Khavandi A, Moynagh A, Chowdhary S, Spence MS, Brown S, Khan SQ, Walker N, Trivedi U, Hutchinson N, De Belder AJ, Moat N, Blackman DJ, Levy RD, Manoharan G, Roberts D, Khogali SS, Crean P, Brecker SJ, Baumbach A, Mullen M, Laborde JC, Hildick-Smith D (2011) Permanent pacemaker insertion after corevalve transcatheter aortic valve implantation: incidence and contributing factors (the UK corevalve collaborative). Circulation 123:951-960

73. Buellesfeld L, Stortecky S, Heg D, Hausen S, Mueller R, Wenaweser P, Pilgrim T, Gloekler S, Khattab AA, Huber C, Carrel T, Eberle B, Meier B, Boekstegers P, Juni P, Gerckens U, Grube E, Windecker $S$ (2012) Impact of permanent pacemaker implantation on clinical outcome among patients undergoing transcatheter aortic valve implantation. J Am Coll Cardiol 60:493-501

74. Sinning JM, Vasa-Nicotera M, Chin D, Hammerstingl C, Ghanem A, Bence J, Kovac J, Grube E, Nickenig G, Werner N (2013) Evaluation and management of paravalvular aortic regurgitation after transcatheter aortic valve replacement. J Am Coll Cardiol 62:11-20

75. Abdel-Wahab M, Zahn R, Horack M, Gerckens U, Schuler G, Sievert H, Eggebrecht H, Senges J, Richardt G (2011) Aortic 
regurgitation after transcatheter aortic valve implantation: incidence and early outcome. Results from the german transcatheter aortic valve interventions registry. Heart 97:899-906

76. Tamburino C, Capodanno D, Ramondo A, Petronio AS, Ettori F, Santoro G, Klugmann S, Bedogni F, Maisano F, Marzocchi A, Poli A, Antoniucci D, Napodano M, De Carlo M, Fiorina C, Ussia GP (2011) Incidence and predictors of early and late mortality after transcatheter aortic valve implantation in 663 patients with severe aortic stenosis. Circulation 123:299-308

77. Binder RK, Rodes-Cabau J, Wood DA, Mok M, Leipsic J, De Larochelliere R, Toggweiler S, Dumont E, Freeman M,
Willson AB, Webb JG (2013) Transcatheter aortic valve replacement with the sapien 3: a new balloon-expandable transcatheter heart valve. JACC Cardiovasc Interv 6:293-300

78. Wenaweser P, Stortecky S, Schwander S, Heg D, Huber C, Pilgrim T, Gloekler S, O'Sullivan CJ, Meier B, Juni P, Carrel T, Windecker S (2013) Clinical outcomes of patients with estimated low or intermediate surgical risk undergoing transcatheter aortic valve implantation. Eur Heart J 34:1894-1905 